J. Clin. Chem. Clin. Biochem.

Vol. 27, 1989, pp. 797-802

(C) 1989 Walter de Gruyter \& Co.

Berlin - New York

\title{
Development and Validation of a Radioimmunoassay for Serum Melatonin
}

By B. Manz

Abteilung für Experimentelle Endokrinologie der Johannes Gutenberg Universität, Mainz, FRG

A. Seidel

Anatomisches Institut der Johannes Gutenberg Universität, Mainz, FRG

H. Alexander

Klinik für Gynäkologie und Geburtshilfe, Karl-Marx-Universität, Leipzig, GDR

L. Vollrath

Anatomisches Institut der Johannes Gutenberg Universität, Mainz, FRG

B. Wagner

Abteilung für Experimentelle Endokrinologie der Johannes Gutenberg Universität, Mainz, FRG

G. Zimmermann

Klinik für Gynäkologie und Geburtshilfe, Karl-Marx-Universität, Leipzig, GDR

K. Wiedemann

Psychiatrische Universitäts-Klinik Freiburg, FRG and

K. Pollow

Abteilung für Experimentelle Endokrinologie der Johannes Gutenberg Universität, Mainz, FRG

(Received February 2/June 13, 1989)

Summary: A radioimmunoassay using N-[3-(4-hydroxy-3-[4-hydroxy-3-[25I]iodophenylpropionyl)]-5-methoxytryptamine as tracer for determination of melatonin in the serum of different species is described. Melatonin antisera were raised in rabbits by immunization with a bovine serum albumin conjugate of N-[3-(2-aminoethyl)5-methoxy indole] hemisuccinamide. A single high affinity, specific antiserum was obtained. In contrast to previous studies, the tracer was synthesised in one step in the absence of water, giving an excellent yield of highly pure product. No chromatogräphic purification step was needed. Polyethylene glycol in combination with goat antirabbit immunoglobulins was used to separate bound and unbound tracer. Sera were delipidized with Lipoclean ${ }^{\circledast}$ prior the extraction of melatonin with diethyl ether. This sample preparation allows the determination of melatonin in the presence of widely varying amounts of lipids in human, rat and hamster serum. Using this extraction procedure, the sensitivity of the radioimmunoassay was approximately $1 \mathrm{ng} / \mathrm{lof}$ serum. Dilutions of sera and of synthetic melatonin gave the same parallel response in the radioimmunoassay. High performance liquid chromatography analysis of a serum extract showed only one immunoreactive peak co-eluting with synthetic melatonin. Characteristic diurnal rhythms of melatonin were observed in all species. All assay components including standards and serum controls are stable for at least 1 year at $4{ }^{\circ} \mathrm{C}$, thus facilitating the determination of melatonin in a routine laboratory. 


\section{Introduction}

Many of the physiological functions of the pineal gland are mediated by its hormone melatonin (1). Comparative investigations into the endocrine function of the pineal in different species often focus on the quantitative estimation of melatonin, especially in plasma or serum. Radioimmunoassay is the most widely used technique to determine this hormone (2). Although a multitude of excellent radioimmunoassay procedures have been described (3-7), the need for an easy to handle and generally applicable test system for serum/plasma of different species is evident.

This report describes an assay using an iodinated tracer of high purity and a specific sample preparation which allows the determination of melatonin even in the presence of large amounts of lipids. The excellent stability of all assay components, the short incubation times and the double antibody technique facilitate the determination of melatonin in a routine laboratory.

\section{Materials and Methods}

\section{Chemicals}

N-Succinimidyl-3-(4-hydroxy-5(3)-[125I]iodophenyl)propionate ${ }^{125}$ I-labelled Bolton-Hunter reagent, $74 \mathrm{EBq} / \mathrm{mol}$ and $\left[{ }^{3} \mathrm{H}\right]$ melatonin $(1.1 \mathrm{EBq} / \mathrm{mol})$ were purchased from New England Nuclear Corp. (Dreieich, F. R. G.). Bovine serum albumin was obtained from Behring Institut (Marburg, F. R. G.). Melatonin and its analogues were from Sigma (München, F. R. G.) and Aldrich (Nettetal, F. R. G.). Analytical grade chemicals and glass-destilled water were used throughout.

\section{Buffers}

Buffer A: $50 \mathrm{mmol} / \mathrm{l}$ potassium phosphate, $\mathrm{pH} 7.0$, containing $3 \mathrm{mmol} / \mathrm{l}$ sodium azide and $1 \mathrm{~g} / 1$ gelatine. Buffer $\mathrm{B}$ : buffer $\mathrm{A}$ supplemented with $1 \mathrm{~g} / \mathrm{l}$ ascorbic acid.

\section{Precipitating antiserum reagent}

The precipitating antiserum (goat anti-rabbit immunoglobulins) was diluted 25 -fold with phosphate-buffered saline and mixed $1+1$ with the same buffer containing $120 \mathrm{~g} / \mathrm{l}$ polyethylene glycol 4000 prior to use. One $\mathrm{ml}$ of precipitating antiserum was used per assay tube.

Preparation of the immunogen, and immunisation

The immunogen used consisted of 5-methoxytryptamine hemisuccinamide bound to bovine serum albumin as described by Rollag \& Niswender (8). The molar ratio of hapten conjugated to protein was not directly assessed. Twenty rabbits were immunized by an initial dorsal injection of an emulsion of $0.5 \mathrm{ml}$ $(1 \mathrm{mg})$ of immunogen and $0.5 \mathrm{ml}$ of complete Freund's adjuvant. Booster injections were given in the same way at intervals of 4 weeks, except that incomplete Freund's adjuvant was used. Blood samples were tested 1 week after each booster injection.
Synthesis of N-[3-(4-hydroxy-3-[125 I]iodophenylpropionyl)]-5-methoxytryptamine

Five mg of 5-methoxytryptamine were dissolved in $500 \mu \mathrm{l}$ dry pyridine. Aliquots $(10 \mu \mathrm{l})$ of this solution were mixed with appropriate amounts of ${ }^{125} \mathrm{I}$-labelled Bolton-Hunter reagent and the mixture was incubated overnight at $4{ }^{\circ} \mathrm{C}$. The organic solvents were removed under a gentle stream of nitrogen and the residue was dissolved in $500 \mu \mathrm{l}$ of buffer B. The solution was applied to a disposable Extrelut $1^{\otimes}$ column and extracted with $6 \mathrm{ml}$ of ethyl acetate. The ethyl acetate was removed at room temperature under nitrogen and the N-[3-(4-hydroxy-3$\left[{ }^{125} \Pi\right]$ iodophenylpropionyl)]-5-methoxytryptamine redissolved in $1 \mathrm{ml}$ of buffer B. Appropriate amounts of the conjugate were diluted with buffer $A$ to a final radioactivity of $10 \mathrm{MBq} / \mathrm{l}$ and enriched with $0.2 \mathrm{~g} / 1$ of purified rabbit immunoglobulins.

\section{Human serum sample preparation}

To avoid clotted fibrin, human blood samples were collected by use of Monovette syringes (Sarstedt, Nümbrecht, F.R. G. or similar products), and centrifuged at $1500 \mathrm{~g}$. The serum was separated and frozen at $-20^{\circ} \mathrm{C}$ before analysis.

\section{Preparation of serum controls}

One litre of serum collected at $14.00 \mathrm{~h}$ was obtained from the hospital blood bank and the melatonin content determined by radioimmunoassay to be $7 \mathrm{ng} / \mathrm{l}$. Three hundred $\mathrm{ml}$ aliquots were enriched with either 12 or $24 \mathrm{ng}$ of melatonin in $1 \mathrm{ml}$ of 0.1 $\mathrm{mol} / 1$ hydrochloric acid and $1 \mathrm{ml}$ portions containing either 47 or $87 \mathrm{pg}$ of melatonin were lyophilized without heating. The lyophilized controls are stable for at least 1 year when stored at $4{ }^{\circ} \mathrm{C}$.

\section{Extraction of melatonin}

One $\mathrm{ml}$ of serum and $2 \mathrm{ml}$ of Lipoclean ${ }^{\circ}$ (Behring, Marburg, F.R.G.) were pipetted into a glass centrifuge tube, heated to $37^{\circ} \mathrm{C}$ and mixed on a rotation mixer for at least 1 minute Separation of the two phases was accelerated by 5 min centrifugation at $1500 \mathrm{~g}$, and $500 \mu \mathrm{l}$ of the upper clear serum phase were transferred into a glass extraction tube. Four $\mathrm{ml}$ of diethy ether (Uvasol quality, Merck, Darmstadt, F. R. G.) were added and the phases mixed for $1 \mathrm{~min}$ on a rotation mixer. The lower serum phase was frozen and the ether phase decanted into a glas vial. The ether was removed, $500 \mu$ lof buffer $A$ were added and the extract stored at $0-4^{\circ} \mathrm{C}$ until use.

\section{Preparation of melatonin-free human serum}

One litre of serum, from the hospital blood bank, was gently shaken with $10 \mathrm{~g} / \mathrm{l}$ charcoal (Norit A, Merck, Darmstadt) for 3 hours at room temperature. The charcoal was removed by 30 min centrifugation at $10000 \mathrm{~g}$ and the serum stored at $-20^{\circ} \mathrm{C}$.

\section{Preparation of standards}

\section{Buffer standards}

Melatonin was diluted in buffer A from a $1 \mathrm{~g} / 1$ stock solution in ethanol to the following concentrations: $10,40,150,500$ and $2000 \mathrm{ng} / \mathrm{l}$. One ml aliquots were lyophilized without heating. The lyophilized standards were redissolved in $2 \mathrm{ml}$ of double distilled water prior to use. 


\section{Serum standards}

Lyophilized buffer standards were redissolved in two $\mathrm{ml}$ of melatonin-free serum and lyophilized without heating. The lyophilized serum standards were redissolved in $2 \mathrm{ml}$ of double distilled water prior to use. Both sets of standards are stable for at least 1 year.

\section{Radioimmunoassay procedure}

Sample $(200 \mu \mathrm{l})$ and diluted antiserum $(50 \mu \mathrm{l})$ (final dilution $1: 12000$ ) were pipetted to a polystyrene tube and incubated 2 hours at $37^{\circ} \mathrm{C}$ or overnight at $4{ }^{\circ} \mathrm{C}$. Tracer $(50 \mu \mathrm{l})$ was added and the tubes incubated for 1 hour at $4^{\circ} \mathrm{C}$. One $\mathrm{ml}$ of precipitating antibody was added, the mixture incubated for $30 \mathrm{~min}$ utes at $4{ }^{\circ} \mathrm{C}$ and centrifuged. The supernatant was aspirated and the pelleted radioactivity determined in a gamma-counter. Each series consisted of a standard curve 5-1000 ng/l (1-200 $\mathrm{pg} /$ tube), tubes for the determination of unspecific binding, quality control samples and the samples to be assayed.

\section{Cross-reactivity studies}

The specificity of the antiserum was assessed by comparing the displacement of antibody-bound N-[3-(4-hydroxy-3-[125I]iodophenylpropionyl)]-5-methoxytryptamine by a number of indoles (tab. 1).

\section{Physiological studies}

\section{Human}

Blood was sampled (September) at the indicated intervals by an indwelling cannula from six normal healthy female subjects, aged $18-34$ years.

Rat

Male Sprague-Dawley rats were killed at the indicated times by decapitation, trunk blood was collected and serum was stored at $-70^{\circ} \mathrm{C}$ until assayed.

\section{Male golden hamster}

Sera were a gift of Dr. Pevet, University of Strasbourg, France.

\section{Results}

\section{Tracer synthesis}

5-Methoxytryptamine was labelled according to Tiefenauer \& Andres (6). In contrast to their acylation procedure we developed a labelling scheme in the absence of water, which rendered a further chromatographic purification unnecessary (fig. 1). The overall yièld was $95 \%$ as compared to $38 \%$ reported by these authors. The stäbility of the concentrated tracer was at least one half-life period.

\section{Antibody preparation}

Six of 20 rabbits immunized produced titratable antisera following the third booster immunization. The highest titres (final dilutions of $1: 60000$ ) were ob-

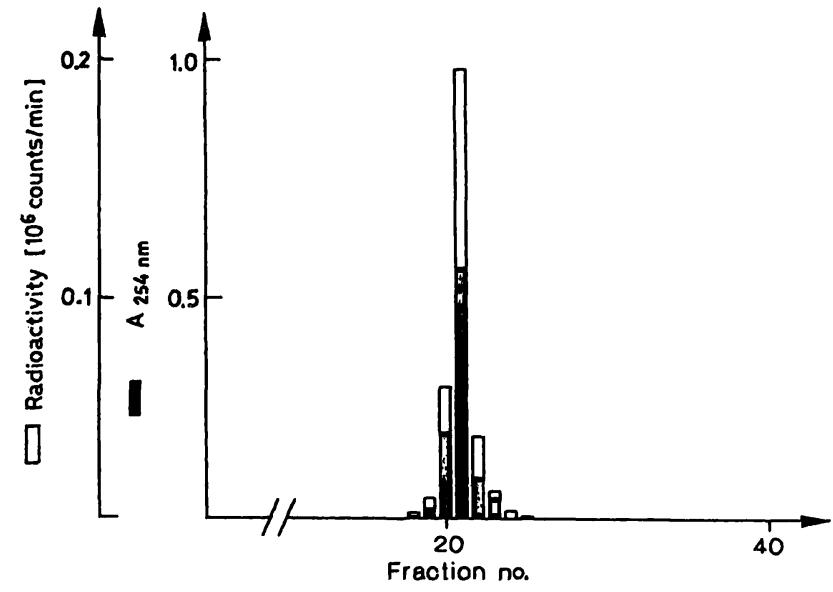

Fig. 1. Purity of N-[3-(4-hydroxy-3-[25I]iodophenylpropionyl)] -5 -methoxytryptamine.

N-[3-(4-hydroxy-3-[125I]iodophenylpropionyl)]-5-methoxytryptamine was submitted to reversed phase high performance liquid chromatography on a PEP RPC column (Pharmacia, Freiburg, F. R. G.) using an increasing methanol gradient. [ $\square$ ] counts/min per fraction $\left({ }^{125} \mathrm{I}\right)$ [ [ ] Authentic N-[3-(4-hydroxy-3[ ${ }^{125}$ I] iodophenylpropionyl)]-5-methoxytryptamine (determined at $254 \mathrm{~nm}$ ).

tained after the sixth booster immunization. All antisera were characterized for antibody specificity, detection limits, binding affinity for both $\left[{ }^{3} \mathrm{H}\right]$ melatonin and the N-[3-(4-hydroxy-3-[ $\left.{ }^{125} I\right]$ iodophenylpropionyl)]-5-methoxytryptamine, and their non-specific interaction with lipophilic serum components. The antiserum showing the highest sensitivity was characterized most fully, and this antiserum is described in the present communication.

\section{Characterization of the antiserum}

Interference of indolic analogues with the antiserum is shown in table 1. The greatest interference was shown by 6-hydroxymelatonin, which is also the principal metabolite (9). However, isocratic high performance liquid chromatography of $5 \mathrm{ml}$ of extracted human pool serum, according to a previously described procedure (10), showed no immunoreactivity other than endogeneous or authentic melatonin (fig. 2).

Tab. 1. Cross-reactivity data

\begin{tabular}{ll}
\hline Compound & Cross-reaction (\%) \\
\hline Melatonin & 100 \\
5-Methoxytryptophol & $<0.5$ \\
6-Hydroxymelatonin & $<0.8$ \\
5-Methoxytryptamine & $<0.01$ \\
Serotonin & $<0.01$ \\
N-Acetylserotonin & $<0.1$ \\
5-Methoxytryptophan & $<0.001$ \\
5-Hydroxy-3-indole acetic acid & $<0.001$ \\
\hline
\end{tabular}




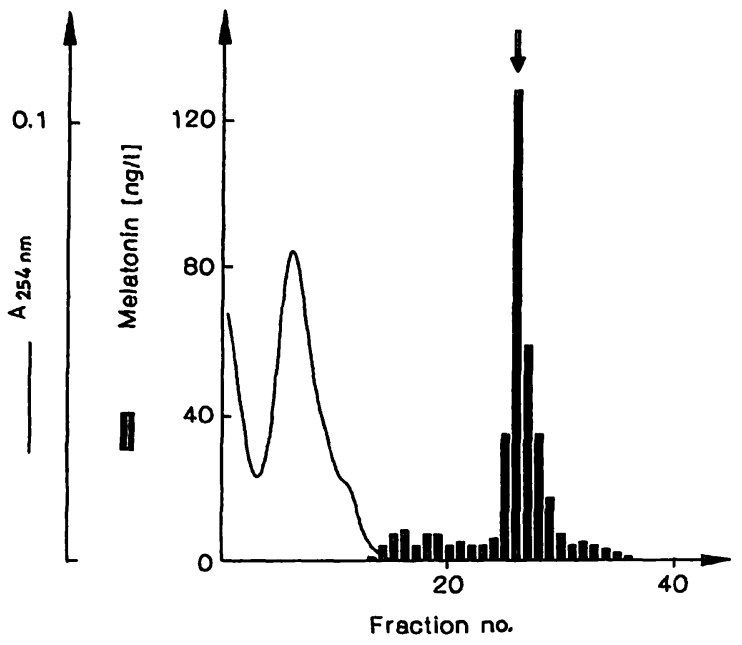

Fig. 2. High performance liquid chromatography of human night serum pool extract.

Human night serum $(5 \mathrm{ml})$ was extracted with diethyl ether as described in Material and Methods. In contrast to the radioimmunoassay procedure, the extract was redissolved in water/methanol $(9+1$, by vol.) and submitted to isocratic reversed phase high performance liquid chromatography on a PEP RPC column. Fractions of $1 \mathrm{ml}$ were collected, lyophilized and the melatonin content determined by radioimmunoassay. The arrow $(\downarrow)$ indicates the retention time of authentic melatonin.

Similar results were found for rat and hamster serum extracts (data not shown). All other analogues showed negligible interference at the concentrations normally present in blood.

The affinity constants of the antiserum for $\left[{ }^{3} \mathrm{H}\right]$ melatonin and $\mathrm{N}-\left[3-\left(4-h y d r o x y-3-\left[{ }^{125} \mathrm{~T}\right]\right.\right.$ iodophenylpropionyl)]-5-methoxytryptamine as determined by Scatchard-plot analysis (11) were $10^{-10}$ and $2 \times 10^{-11} \mathrm{~mol} / \mathrm{l}$, respectively.

The sensitivity of the antiserum was determined with a view to the application of the assay in a clinical routine laboratory. Therefore a spread of 10000 counts/min for a sufficient counting accuracy and a tracer concentration of approximately 30000 counts/ min per tube (to limit the consumption of ${ }^{125}$ Iodine) was mandatory. Under these conditions a standard curve of $1 \mathrm{pg}\left(80 \% \mathrm{~B} / \mathrm{B}_{\mathrm{o}}\right)-250 \mathrm{pg}\left(20 \% \mathrm{~B} / \mathrm{B}_{\mathrm{o}}\right)$ melatonin per assay tube could be established with $50 \%$ displacement at $10 \mathrm{pg}$ per vial. The assay dilution of antiserum was $1: 12000$.

Sensitivity of the antiserum against coextracted human lipophilic serum components is exemplified for an extreme case in figure 3. This lipophilic component led to unusually high melatonin values. Although this effect appeared more or less in all sera of different species, its magnitude was not predictable but was greatest when blood fats were raised by food intake.

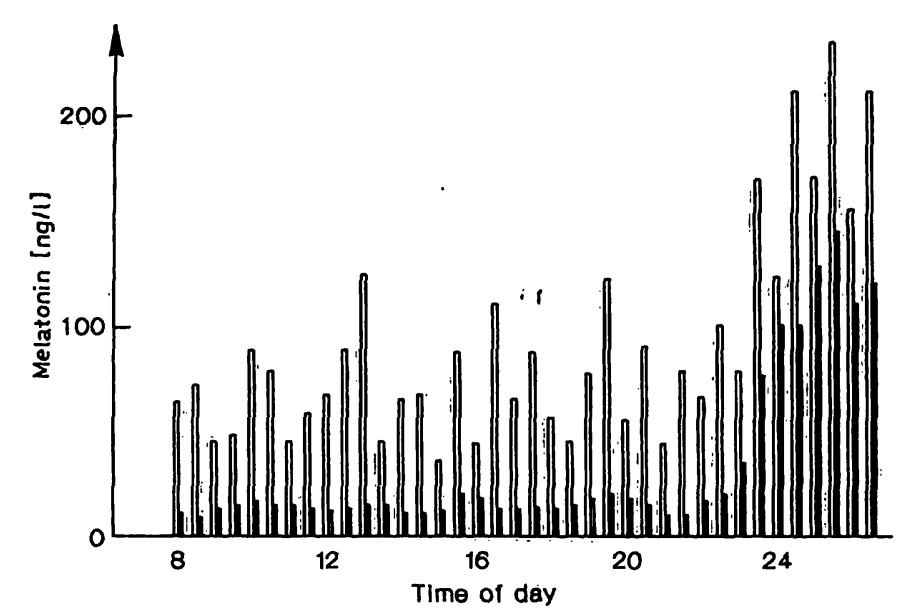

Fig. 3. Dištortion of radioimmunoassay results by blood fats. Blood samples of a healthy male volunteer were collected at $30 \mathrm{~min}$ intervals. Samples $(250 \mu \mathrm{l})$ were either extracted directly with diethyl ether (open bars), or extracted after pretreatment with Lipoclean ${ }^{(1)}$ (filled bars).

Pretreatment of serum with Lipoclean ${ }^{\circledR}$ removed this effect quantitatively without reducing the melatonin content of serum samples (data not shown). In the absence of serum proteins, however, melatonin is extracted into the Lipoclean ${ }^{\circledR}$ phase. Parallelism between the melatonin standard curve and charcoaltreated early afternoon serum enriched with identical amounts of melatonin is shown in table 2 . Both curves are superimposable. Regression analysis gave $y=0.87 x-3.9(r=0.99)$. This corresponds with the losses of melatonin during sample extraction.

Tab. 2. Parallelism of buffer standards and extracted serum standards

\begin{tabular}{|c|c|c|}
\hline \multirow{2}{*}{$\begin{array}{l}\text { Buffer standards } \\
\text { (ng/l) }\end{array}$} & \multicolumn{2}{|c|}{ Serum standards } \\
\hline & $\begin{array}{l}\text { expected } \\
\text { (ng/l) }\end{array}$ & found* \\
\hline $\begin{array}{r}5 \\
20 \\
75 \\
250 \\
1000\end{array}$ & $\begin{array}{r}5 \\
20 \\
75 \\
250 \\
1000\end{array}$ & $\begin{array}{c}4.3 \\
16 \\
65.2 \\
201 \\
970\end{array}$ \\
\hline
\end{tabular}

* Mean of three different determinations

\section{Assay characteristics}

Within-day coefficient of variation of the zero-dose standard is $<2 \%$. Therefore, the minimal detectable concentration is the concentration at which $\mathrm{B} / \mathrm{Bo}$ is approximatly $0.96(1-2$ times the coefficient of variation), or $1 \mathrm{ng}$ melatonin per litre of standard. 
Intra-assay and inter-assay variances for pooled human night serum were 11 and $12 \%$, respectively. Pooled rat serum (night) had variances of 10 and $13 \%$, pooled hamster serum (day) had variances of 12 and $15 \%$. Recoveries of tritiated melatonin from human, rat and hamster serum pools were $85 \pm 5 \%$.

\section{Physiological studies}

\section{Human}

Circadian rhythms of serum melatonin in 6 healthy female volunteers are shown in figure 4. Mean serum levels of melatonin in the whole group varied from $30 \pm 3( \pm \mathrm{SEM})$, range $11-44 \mathrm{ng} / 1$ at $16.00 \mathrm{~h}$ to $135 \pm 40( \pm \mathrm{SEM})$ at $24.00 \mathrm{~h}$, range $44-170 \mathrm{ng} / \mathrm{l}$.

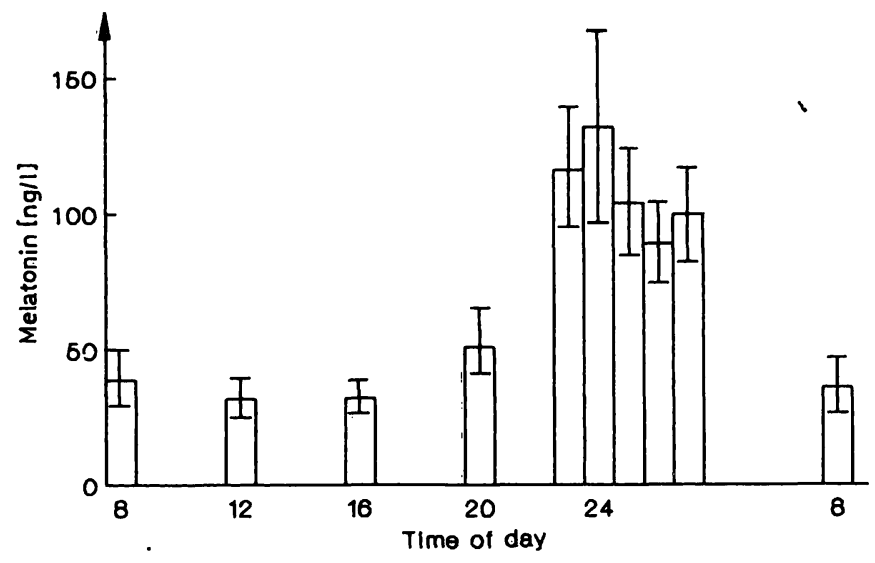

Fig. 4. Melatonin circadian rhythm in 6 normal females (mean \pm SEM).

\section{Rat}

Animals killed during the dark phase $(24.00 \mathrm{~h})$ had higher melatonin levels than serum of rats collected at $12.00 \mathrm{~h}$. Parallelism between serial dilutions of night serum and the standard curve was established. Recovery of added melatonin was $97 \pm 5 \%$ (corrected for extraction losses).

\section{Discussion}

A radioimmunoassay for serum melatonin was developed, based on the work of Rollag \& Niswender (8): In this paper we describe the optimization of

\section{References}

1. Reiter, R. J. (1980) The pineal in the control of reproduction in mammals. Endocrinol. Rev. 1, 109-131.

2. Brown, G. M., Grota, L. J. \& Pulido, O. (1983) Application of immunologic techniques to the study of pineal indolealkylamines. In: Pineal Research Reviews, Vol. 1 (Reiter, R. J., ed.) New York: Alan R. Liss Inc. pp. 207-246. sample preparation by use of delipidization of serum samples with Lipoclean ${ }^{\circledR}$ prior to the assay, the long term stabilization of assay components (standards, controls, tracer) and a simplified tracer synthesis with superior yields.

The tracer was found to be of high purity and no further purification was necessary. Moreover, all steps of synthesis can be performed using disposable standard equipment. In the presence of the antioxidant ascorbic acid, the concentrated tracer wás stable for at least one half-life period.

Six of twenty rabbits produced antibodies, thus demonstrating suitability of the antigen, but only one antiserum exhibited a sufficient sensitivity for development of the present assay. Due to the homology of antigen and tracer, the affinity for the antibody of $\mathrm{N}$ acyl analogues of 5-methoxytryptamine, such as $\mathrm{N}$ [3-(4-hydroxy-3-[125I]iodophenylpropionyl)]-5-methoxytryptamine, is several-fold higher than that of melatonin. Therefore a preincubation of antiserum with standards and extracted samples prior to addition of the tracer was necessary to enhance assay sensitivity.

For routine purposes ether extraction has many advantages over the widely used chloroform extraction (5). However, coextracted lipids may strongly distort the assay results, most probably by non-specific inhibition of the antibody-antigen reaction. As this effect is not predictable, the introduction of a delipidization step was mandatory. Surprisingly, in the presence of serum proteins, melatonin is retained in the aqueous phase, whereas lipids (as well as other lipophilic components) are extracted into the organic phase. The validity of the radioimmunoassay was confirmed by parallel displacement between standards and extracted samples enriched with identical amounts of melatonin, as well as the identification of endogenous melatonin by high performance liquid chromatographic fractionation of a serum pool extract.

The present results for the diurnal rhythms of melatonin, with low day and high night levels in human and rat serum, are in good agreement with previous reports (for review see 1.c. (12)).

3. Arendt, J., Wetterberg, L., Heyden, T., Sizonenko, P. C. \& Paunier, L. (1977) Radioimmunoassay of melatonin: human serum and cerebrospineal fluid. Hormone Res. $\mathcal{S}$, $65-75$. 
4. Grota, L. J., Snieckus, V., De Silva, S. O., Tsui, H. V., Holloway, W. R., Lewy, A. J. \& Brown, G. M. (1981) Radioimmunoassay of melatonin in rat serum. Prog. Neuro-Psychopharmacol. 5, 523-526.

5. Vakkuri, O., Leppäluoto, J. \& Vuolteenaho, O. (1984) Development and validation of a melatonin radioimmunoassay using radioiodinated melatonin tracer. Acta Endocrinol. $106,152-157$.

6. Tiefenauer, L. X. \& Andres, R. Y. (1984) Prevention of bridge binding effects in haptenic immunoassay systems exemplified by an iodinated radioimmunoassay for melatonin. J. Immunol. Meth. 74, 293-298.

7. Sieghart, W., Ronca, E., Drexler, G. \& Karall, S. (1987) Improved radioimmunoassay of melatonin in serum. Clin. Chem. 33, 604-605.
8. Rollag, M. D. \& Niswender, G. D. (1976) Radioimmunoassay of serum concentrations of melatonin in sheep exposed to different lighting régimens. Endocrinology 98 , $482 \div 489$.

9. Kopin, I. J., Pare, C. M. B., Axelrod, J. \& Weissbach, H. (1960) 6-Hydroxylation, the major metabolic pathway for melatonin. Biochim. Biophys. Acta 40, 377.

10. Manz, B., Kosfeld, H., Harbauer, G., Grill, H.-J: \& Pollow, K. (1985) Radioimmunoassay of human serum serotonin. J. Clin. Chem. Clin. Biochem. 23, 657-662.

11. Scatchard, G. (1949) Attraction of small molecules. Ann. N. Y. Acad. Sci. 51, 660-672.

12. Pang, S. F. \& Allen, A. E. (1986) Extra-pineal melatonin in the retina: its regulation and physiological function. Pineal Research Reviews 4, 55-95.

Dr. B. Manz

Abteilung für Experimentelle Endokrinologie Johannes Gutenberg-Universität

Langenbeckstraße 1

D-6500 Mainz 